\title{
Analysis Value Added of Arabica Coffee in Determining the Lowest Unit Price Policy in Buntu Pepasan District, North Toraja Regency
}

\author{
Rico', Rahim Darma², Laode Asrul2, Didi Rukmana², Musran Munizu2, Mahyuddin² \\ ${ }^{1}$ Agribusiness Study Program Student, Post Graduated School of Hasanuddin University, Perintis Kemerdekan Km. 10 Makassar 90245 , Indonesia \\ ${ }^{2}$ Lecturer of Agribusiness Program, Postgraduate School of Hasanuddin University, Perintis Kemerdekan Km. 10 Makassar 90245, Indonesia.
}

Correspondence Author: Rico, Agribusiness Study Program Student, Post Graduated School of Hasanuddin University, Perintis Kemerdekan Km. 10 Makassar 90245, Indonesia

Email: ricosia3@gmail.com

Received date: 28 August 2019, Accepted date: 22 December 2019, Online date: 25 December 2019

Copyright: (C) 2019 Rico et al. This is an open-access article distributed under the terms of the Creative Commons Attribution License, which permits unrestricted use, distribution, and reproduction in any medium, provided the original author and source are credited.

\begin{abstract}
The aims of the research was to analyze the added value of arabica coffee in determining the lowest retail price in the Buntu Pepasan District, North Toraja Regency. This research was conducted in June to July 2019 at Buntu Pepasan Subdistrict, North Toraja Regency, South Sulawesi Province using purposive informants, which were analyzed descriptively quantitatively. The added value obtained by farmers is IDR. 18,994 with a profit rate of $78.67 \%$, then the added value obtained by the trader is IDR. 35,538 with a profit rate of $96.90 \%$, while the added value obtained by the coffeshop was IDR. 53,123 with a profit rate of $96.22 \%$. The profit value shows the amount of compensation received by the entrepreneur. Based on the results of the value added approach that is carried out for each value chain actor in the Arabica coffee commodity, the lowest Arabica Coffee Unit Price policy in North Toraja Regency can be changed to change the selling price at the farmer level from IDR. 18,000 / Liter or IDR. 36,000 / $\mathrm{kg}$ in the form of seeds that are still horn-skinned to IDR. 28,000 per liter or IDR. $\mathbf{5 6 , 0 0 0}$ per kilogram in the form of coffee beans that are still horned.
\end{abstract}

Keywords: Arabica Coffee, Value Added, Fixed Unit Price Determination.

\section{INTRODUCTION}

Arabica coffee grows in the plains with a minimum altitude of 900 meters above sea level (masl). Arabica coffee exports increased by $9.2 \%$ annually. Up to $40 \%$ of exported Arabica coffee is better known as single-origin coffee or geographic coffee. Small farms in South Sulawesi Province produce an average of $12.50 \%$ of Arabica coffee from Indonesia, which is equivalent to 20,10 thousand tonnes per year. In 2015, Arabica coffee produced by community plantations in the province reached 20.35 thousand people. One of the largest Arabica coffee production centers in South Sulawesi Province is in the regency of Toraja North. In 2017, it accounted for $10.37 \%$ of production, representing a total production of 2,11 thousand tonnes [1].

With the large amount of Arabica coffee produced in the northern regency of Toraja, Arabica coffee producers in the North Toraja Regency have problems with domestic coffee sales prices. Fluctuations in world market prices affecting local prices often force farmers to sell their coffee below market prices to make ends meet. The cost of gambling was all the more caused by the absence of the lowest unit price created by the local government to protect farmers from the behavior of collectors entrusted by large companies.

The paradigm of agricultural development is the realization of a healthy and productive and creative society through resilient agriculture based on local resources [2].In recent years, the quest for knowledge regarding coffee is spreading due to the growing appreciation of coffee. Consumers are no longer content with instant coffee and now crave for the experience as well as flavors of freshly roasted-high quality coffee. The quality of the coffee beverage is closely related to the chemical composition of the roasted beans, which is affected by the composition of green beans and postharvest processing conditions, i.e., drying, storage, roasting and grinding [3]. Antioxidant as caffeine and chlorogenic acid (CGA) and total phenolic acid were determined in Arabic and green coffee shows that the green coffee was higher in caffeine, CGA and total phenolic acid $(2.10 \%, 9.74 \%$, and 366.0 $\mathrm{mg} / 100 \mathrm{~g}$ ) than Arabic coffee was $1.5 \%, 7.80 \%$, and $206.0 \mathrm{mg} / 100 \mathrm{~g}$, respectively. The results showed that the green coffee beans, significantly decrease in caffeine, chlorogenic acid and total phenolic acid after roasting may be caused the thermal effect on the antioxidant during the drying of green coffee[4]. 
By maintaining the product remains fresh until up to the consumer. Distance becomes one of determining the quality of fresh produce. Therefore, the supply chain is not only delivered the goods to reach the consumers, but the product still has value by consumer demand. In presenting added benefit, he must emphasize the principle of efficiency to achieve the supply chain targets [5]. The logistics and supply chain management are no doubt, one of the critical successes, should the country and its economy be competitive and survive. Activities in the supply chain begin with the demand from consumers and end with the business of payment by the consumer after the request is fulfilled [6]. As the price of coffee in the country is still uneconomic and unprofitable, many farmers do not pay attention to coffee, which would affect the quality of the coffee produced, so that many coffee beans do not respond to coffee quality standards for export other plants. Because of these problems, it is necessary to research the effects of the lowest unit price on Arabica coffee, to protect farmers, increase their incomes and encourage Indonesia to become more competitive, to become the largest coffee exporter in the world and to generate foreign exchange. The purpose of this research is to formulate the lowest unit price policy for Arabica coffee in the North Toraja Regency, which serves as a benchmark for the average selling price of Arabica coffee, followed by its impact on farmers in terms of production yield and quality.

\section{RESEARCH METHODS}

This research was conducted in June to July 2019 in BuntuPepasan District, North Toraja Regency, South Sulawesi Province. The study was conducted at a location that was determined intentionally (purposive) with the consideration that the selected location was the best Arabica coffee production center, using informants purposive analyzed quantitative descriptive. This study aims to formulate the lowest unit price policy for Arabica coffee in BuntuPepasan District, North Toraja Regency which is used as a reference for the average selling price of Arabica coffee (actual price).

Data analysis in research is the process of systematically searching and compiling data obtained from observations and interviews by organizing data into categories, describing it into units, synthesizing, compiling into patterns, choose what is essential and what will be learned and make conclusions so that it is easily understood by yourself and others [7].

The data collected from the field came from key informants, such as members, North Toraja Regent, headman, and field extension officers, then the data was processed and analyzed using the theory of policy formulation stages by [8] namely the formulation of the problem, the policy agenda, the selection of alternative policies to solve the problem, and the steps of determining the policy.

\section{RESULTS AND DISCUSSION}

\section{A. General Description of The Added Value of Arabica Coffee}

1. The income of Arabica Coffee Farmer

Research of the lowest unit price policy based on facts found by researchers at the research site in the Buntu Pepasan subdistrict, it is necessary to determine the most economical price because of low income received by farmers to affect the quality and quantity of coffee production. Agricultural receipts are multiplications between production and product prices [9]. Calculation of income of coffee farmers (30 respondents) based on revenues from coffee plantations reduced by other ancillary costs. The production costs of arabica coffee producers are the cost production facilities, labor, depreciation costs, and PBB costs.

Table 1: Arabica Coffee Farmer Income in North Toraja Regency

\begin{tabular}{|c|c|c|}
\hline No & Variable & Value \\
\hline 1 & Acceptance: & 1.290 \\
\hline & a. Production (Kg) & 36.000 \\
\hline & b. Product Price (IDR/Kg) & $\mathbf{3 4 . 2 0 0 . 0 0 0}$ \\
\hline & \multicolumn{1}{|c|}{ Acceptance Value (IDR) } & 5.320 .000 \\
\hline 2 & Production Costs & 5.750 .000 \\
\hline & a. Production Facilities & 7.458 .167 \\
\hline & b. Labor & 2.775 .000 \\
\hline & c. Depreciation Costs & $\mathbf{2 1 . 3 0 3 . 1 6 7}$ \\
\hline & d. PBB Costs Total Cost & 12896833 \\
\hline 3 & Income (IDR) & $\mathbf{2 . 0}$ \\
\hline
\end{tabular}

Source: Primary data that has been processed, 2019

Based on the data presented in the income 30 farmers' income, acceptance of farmer is IDR 34.200.000,- and average production costs per a crop is IDR 21.303.167,-. Comparison between acceptance values of farmers divided by the total production cost obtained from the R / C ratio of 2.00. Price conditions in the study of coffee products with an average of IDR. 18,000 / L or IDR. $36,000 / \mathrm{Kg}$. 
2. The Added Value of Arabica Coffee

Added value generated by Arabica coffee products was based on actors of the value chain and all of the stakeholders. There are Three chains are form in BuntuPepasanDistrict, Toraja Regency are farmers, collectors and home industries Staircase / Coffeeshop.

Table 2: Calculation of Value Added Arabica Coffee in North Toraja Regency, 2019.

\begin{tabular}{|c|c|c|c|c|}
\hline No. & Variable & Farmers & Collector & The Home Industry/Coffeeshop \\
\hline \multicolumn{5}{|c|}{ Output, input, and price } \\
\hline 1 & Output (Kg/year) & 10.952 & 35.400 & 38.240 \\
\hline 2 & Raw Materials (Tree-Kg) & 18.883 & 43.000 & 47.800 \\
\hline 3 & Workers (HOK) & 1.538 & 936 & 3.202 \\
\hline 4 & Conversion factors $(1 / 2)$ & 1 & 1 & 1 \\
\hline 5 & The coefficient of labor $(3 / 2)$ & 0 & 0 & 0 \\
\hline 6 & Output price (IDR/kg) & 36.000 & 90.000 & 250.000 \\
\hline 7 & Average wages (IDR/HOK) & 50.000 & 50.000 & 30.000 \\
\hline \multicolumn{5}{|c|}{ Receipts and Benefits } \\
\hline 8 & Price of Raw Materials (IDR/kg) & 1.020 & 36.000 & 90.000 \\
\hline 9 & Other input values (IDR) & 866 & 2.262 & 56.877 \\
\hline 10 & Output value (IDR/kg) (4x6) & 20.880 & 73.800 & 200.000 \\
\hline \multirow[t]{3}{*}{11} & a. Added value (IDR/kg) (10-9-8) & 18.994 & 35.538 & 53.123 \\
\hline & b. Value added ratio (\%) & \multirow{2}{*}{1} & \multirow{2}{*}{0} & \multirow{2}{*}{0} \\
\hline & $((11 \mathrm{a}: 10) \times 100 \%)$ & & & \\
\hline \multirow[t]{3}{*}{12} & a. Employee benefits (IDR/kg) $(5 \times 7)$ & 4.050 & 1.100 & 2.010 \\
\hline & b. Value added ratio $(\%)$ & \multirow{2}{*}{0} & \multirow{2}{*}{0} & \multirow{2}{*}{0} \\
\hline & $((12 a: 11 a) \times 100 \%)$ & & & \\
\hline \multirow[t]{3}{*}{13} & a. Profits (IDR/kg) (11a-12a) & 14.944 & 34.438 & 51.113 \\
\hline & Profit Rate (\%) & \multirow{2}{*}{1} & \multirow{2}{*}{1} & \multirow{2}{*}{1} \\
\hline & b. $((13 a: 11 a) \times 100 \%)$ & & & \\
\hline
\end{tabular}

Source: Primary data that has been processed, 2019

Table 2, shows that the output of each chain there is a difference because the treatment or activity, business scale, the amount of labor, the amount of raw materials, and the business management used are very different in each chain. At the level of Arabica coffee farmers has an output of 10,952 Arabica coffee in the form of horn skin, then at the level of the merchant collector shows an output of $35,400 \mathrm{~kg}$ of Arabica coffee in the type of green bean with 43,000 kilograms of horn-skinned coffee with $20 \%$ shrinkage, while the last link namely the home industry/coffee shop produces an output of 38,240 kilograms of Arabica coffee which will be marketed in the form of processed coffee and processed coffee products that are ready for consumption.

Added value is the difference in the value of output with the price of raw materials and other input contributions. The added value is the gross added value because it contains a share of labor income. The added value obtained by farmers is IDR. 18,994 with a profit rate of $78.67 \%$, then the added value obtained by the trader is IDR. 35,538 with a profit rate of $96.90 \%$, while the added value received by the coffee shop was IDR. 53,113 with a profit rate of $96.22 \%$. High product value will provide a high level of profit. The interaction between the level of technology, business management and the quality of human resources largely determines the level of production and the amount of added value generated. The value of the profit is the difference between value-added and labor benefits, so it can be said to be net value-added because labor benefits have reduced it. The profit value shows the amount of compensation received by the entrepreneur.

Value Chain can be formed if all actors in the value chain are active in such a way as to maximize the value that occurs along the chain path.
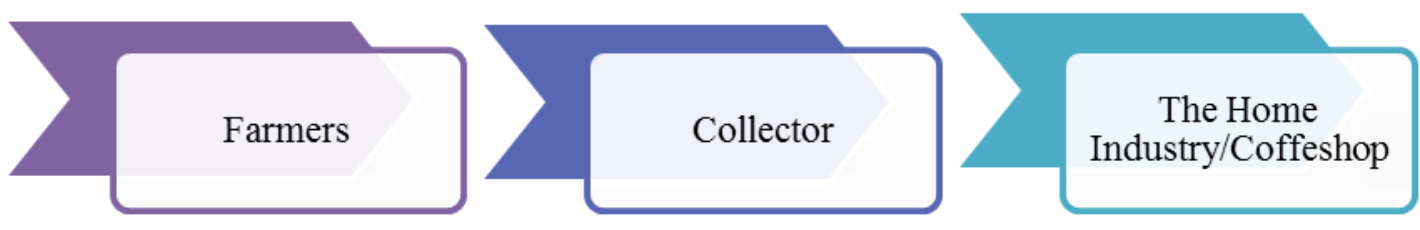

Pictures 1. Arabica Coffee Value Chain in BuntuPepasanDistrict

Based on picture 1, it can be seen that the flow of Arabica coffee products from farmers selling to various directions, to the collector and usually also directly to the Home Industry or Coffeeshop in the form of coffee beans are still horned. The collector is traders who collect Arabica coffee from various villages in BuntuPepasan sub-district even to neighboring sub-districts, then 
collectors sell Arabica coffee beans to the Home Industry / Coffeeshop after drying and stripping the chaff of Arabica coffee beans with the technological help machinery so that Arabica coffee beans are produced in the form of Green Bean. The Home Industry has the same function as Coffeeshop, which is the same value chain that buys Arabica coffee beans in the form of Green Bean from collectors and is given the treatment of frying coffee beans and smoothing in the form of a coffee powder that is ready to be served to consumers or sales in packaging.

Margin is the difference in price at the producer level with the price at the end consumer level. In this case, the margin is calculated from each value chain channel carried out by the value chain actors [10] [11] added that marketing margins are part of the costs paid and the revenue received by each link involved in the process of a value chain. The following is the added value obtained from the margin calculation results.

The added value that occurs in every link, there is a difference significant among farmers, collectors, and home industries/coffeeshop. At the farmer level, profits are low compared to other actors in the chain, due to rising costs production and family needs above income from Arabica coffee plantations. Farmers sell deep Arabica coffee beans the shape of the chaff coffee for IDR. 18000 / liter if converted into kilograms of about 2 liters per kilogram so that farmers receive IDR. 36,000 / kg, then sale to collectors and home industries/coffeeshop.

At the level of the collector, Arabica coffee beans bought in the form of coffee beans chaff are treated in the form of drying and stripping the chaff using a stripping machine. The Collectors sell arabica coffee after receiving a touch of technology and effort drying to increase the sales value of coffee beans in the form of green beans by IDR $70.000,-/ \mathrm{kg}$, which will be sold to the domestic industry/coffeeshop. So buy of farmers and the sale of Arabica coffee beans has a difference that is IDR. 34.000,--

In addition, the domestic/coffeeshop industry buys Arabica coffee beans at green beans collectors at IDR. 70,000/ kg, and then increases the added value of refining the coffee beans to reduce the number of coffee beans to obtain processed coffee beans and coffee grounds using machines sold to consumers at a price of IDR. $270000 / \mathrm{kg}$. At the domestic industry/coffeeshop level, operating costs in the form of labor, cost, raw material prices and other inputs make the selling price of the Arabica coffee powder is high.

3. Determination of the Lowest Unit Price Policy Using The Value Added Method Of Arabica Coffee Products In The Toraja Region

North Toraja Regency has excellent potential of Toraja Arabica Coffee, because of its high production and productivity. South Sulawesi Province is one of the three largest Arabica coffee production centers after the North Sumatra and Aceh provinces. However, this condition will be changed or diminish if farmers don't correctly care with their Arabica coffee plantations, due to the low income of farmers from the sale of their gardening products, so a price policy the lowest is favorable to farmers without harming other chains. Coffee is Indonesia superior commodity in the domestic and international markets, and the government needs to focus on the development of Arabica coffee plantations, following Republic of Indonesia Regulation No.128 of 2014, which states that "Coffee is one of the main spice and refineries products developed to meet export needs." The determination of the policy for the lowest unit price of Arabica coffee can use the theoretical approach proposed by the policy expert, William Dunn, which will be developed as follows. The entire company or related organization is divided into two primary members and supporting members. Primary principal member or members of a supply chain is all business units that perform operational or managerial activities in a business process.

\section{a. Formulation of the problem}

Detecting and formulating questions is a fundamental user of the policy and a significant step in the formulation of the policy. So that the results of the difficulties encountered in the community can be described correctly so that further action can be determined. Based on North Toraja Regulation No. 13 of 2017 concerning the preservation of Genetic Coffee for Toraja Tipika Arabica Coffee, Part Two PuIDRose of Article 3 The purpose of preserving the genetics of Torika Tipika Arabica coffee is to :

a. Protect and preserve the genetics of Arabica Torika coffee;

b. To guarantee price certainty;

c. To increase the income and welfare of coffee producers of Tipika Toraja Arabica and

d. Fostering and empowering the coffee farmers' groups Tipika Toraja Arabica.

On the basis of the above-mentioned regulations, it is assumed that the existence of Arabica coffee producers is necessary because the high-quality product sought can give the name of Indonesia a place in the international market and in particular north of Toraja, also contributing to the increase in regional revenues. Special attention must be paid to coffee growers to be enthusiastic about producing the highest quality Arabica coffee. Therefore, a lower unit price policy for Arabica coffee is needed.

\section{b. Policy Agenda}

In essence, problems in the community will be included in the policy agenda because of the many competing issues. The selected problem for determining the policy in its resolution. Specific criteria for issues deemed essential, namely those that have a significant impact on the community and that requires a quick response to the problem. Given the agricultural situation in Arabica coffee in North Toraja has a problem with prices. Low farm-level sales prices encourage farmers to pay less attention to the conditions of their plantations, as they are less profitable for farmers where the price of rice $36000 / \mathrm{kg}$ is still considered low compared to agricultural activities requiring considerable energy and costs.

After conducting research, Arabica coffee producers expect farmers to expect prices to rise by around IDR. 52.000 - IDR. $60.000 / \mathrm{kg}$ cannot be recommended per-unit price of Arabica coffee to IDR. $28.000 / \mathrm{L}$ or IDR. $56.000 / \mathrm{kg}$ by increasing the 
price received by farmers IDR 10.000 , so that it continues to provide benefits to each marketing institution. Another objective is to increase the income and labor productivity of Arabica coffee producers without harming those who play a role in the Arabica coffee chain. Government attention and local government intervention are needed to include or schedule a policy on the lowest unit price for the welfare of coffee producers Arbika. Another objective is to increase the income and labor productivity of Arabica coffee producers without harming those who play a role in the Arabica coffee chain. Government attention and local government intervention are needed to include or schedule a policy on the lowest unit price for the welfare of coffee producers Arbika. When implementing the price policy agenda, certain aspects of the policy must be determined in advance, namely:

\section{c. Producer price policy}

There are two forms of producer price policy, namely :

1) Shinning Price

Reason: The company doesn't have a competitor yet, a product for the upper class

\section{d. Penetration Price}

Goal: To break the products of other companies on the market

e. Wholesale price policy

This is done for example by granting discounts, both because of cash payments or bulk purchases.

f. Retailer Price Policy

1) Margin Price (based on estimates, if it is already profitable, the products are sold)

2) Lining Price (based on similar items of different brands, at the same price

3) Competitor Price (low prices, the goal is to become the cheapest shop)

4) Judgment Price (based on estimates, in a box, there are one or two pieces of good stuff

5) Customary Price (product prices are stable and there is no change. If the raw material increases, the cost of goods increases

6) Odd Price (odd prices to attract buyers

7) Combination price

g. Choices for problem-solving

Once the problem has been formulated and the agenda has been defined, the next step is to select alternative policies to address the lowest unit price of Arabica coffee at the farm level, to maintain the balance between demand and supply of Arabica coffee at the study site. On the basis of the researchers' findings at the research scene, it is planned to plan the prosperity of coffee growers in accordance with the North Toraja (Perda) Regional Regulation, No. 13 of 2017, has not been heard as it should so that farmers are not enthusiastic about Arabica coffee and the productivity of the land decreases each year. The government, as a policymaker, should adopt policies in favor of Arabica coffee producers, such as setting the lowest unit price of Arabica coffee, without harming those involved in this leading product chain, such as traders and household products and coffee shop industries.

h. Policy Determination Stage

In the final stages of the policy formulation process, according to the theory advanced by an expert named William Dunn, particularly with regard to the establishment or adoption of policies. At this stage, it is necessary to ensure that policy has binding legal force and cannot be challenged and adapted to the applicable laws. In the lowest policy unit pricing step, four steps must be determined, namely:

1) Mark up pricing

The increased price is the cost of buying the product from the producer plus number of benefits and costs are not counted, the total is set a selling price

\section{2) Equilibrium price}

The breakeven point determines the volume of sales to be achieved before the company is in a state of equilibrium, that the total cost is identical to the total income and no profit is realized.

3) Pricing based on the image/perception of the consumer

It is based on the opinion of the value, rather than on costs borne by the seller

4) Prices based on competitors' prices

Set prices according to rates set by competitors for the same product. The price can be the same, higher or lower. The lowest price policy for Arabica coffee in North Toraja will then be divided into the executive board and stakeholder meetings, including Arabica coffee producers, to listen to complaints and reduce producers' incomes. In the culture sector of the Arabica coffee plantation, it will then be proposed to the regional government, in this case, the North Toraja Regent should discuss the finalization of the projection plenary to be determined and approved local regulations of DPRD North Toraja and Governor of South Sulawesi Province. 
The added value obtained by farmers is IDR. 18,994 with a profit rate of $78.67 \%$, then the added value obtained by the trader is IDR. 35,538 with a profit rate of $96.90 \%$, while the added value obtained by the coffeeshop was IDR. 53,123 with a profit rate of $96.22 \%$. The profit value shows the amount of compensation received by the entrepreneur. Based on the results of the valueadded approach that is carried out for each value chain actor in the Arabica coffee commodity, the lowest Arabica Coffee Unit Price policy in North Toraja Regency can be changed to change the selling price at the farmer level from IDR. 18,000/Liter or IDR. 36,000 / kg in the form of seeds that are still horn-skinned to IDR. 28,000 per liter or IDR. 56,000 per kilogram in the form of coffee beans that are still horned.

\section{REFERENCES}

[1] Badan Pusat Statistik . 2017. Toraja Utara. Toraja Utara dalam Angka 2017. Kabupaten Toraja Utara.

[2] Sirajuddin, S. N., Siregar, A. R., Nurlaelah, S., Lestari, V. S., \& Tenrisanna, V. (2017). The limitations and benefits of partnership sharing system of CoIDRorated Cattle Market (CCM). American-Eurasian Journal of Sustainable Agriculture, 11(1), 11-15.

[3] Aliah, A.M. Noor, M. Fareez Edzuan, A.M. Noor Diana. 2015. A Review of Quality Coffee Roasting Degree Evaluation. Journal of Applied Science and Agriculture, 10(7): 18-23. ISSN 1816-9112.

[4] Khojah, Ebtihal Y. 2016. Effect of Arabic and Green Coffee Beans on Lowering Lipid Profile Parameters in Male Rats. Australian Journal of Basic and Applied Sciences,10(18): 310-317. ISSN:1991-8178, EISSN: 2309-8414.AENSI Publisher.

[5] Hastang, Sirajuddin, S. N., Mappangaja, A. R., Darma, R., \& Sudirman, I. (2015). Value added analysis of beef cattle supply chain actors micro-scale community farm based. American-Eurasian Journal of Sustainable Agriculture, 9(7), $7-12$.

[6] Ramingwong, S., \& Sopadang, A. (2015). Simulating Benefits over Supply Chain Redesign Strategies. Journal of Applied Science Research, 7-10.

[7] Sugiyono . 2013. Metodologi Penelitian kuantitatif kualitatif dan R\&D . hlm 335 Cetakan ke-19. Alfabeta . Bandung

[8] Bintari, A dan Pandiangan LHS 2016.Formulasi Kebijakan Pemerintah tentang Pembentukan Badan Usaha Milik Daerah (BUMD) Perseroan Terbatas (PT) Mass Rapid Transit (MRT) Jakarta di Provinsi DKI Jakarta. Jurnal Ilmu Pemerintahan. ISSN 2442-5958, E-ISSN 2540-8674. CosmoGov Vol.2 No.2, halaman 228.

[9] Rahim. Abd. dan Hastuti. DRW. 2007. Ekonomi Pertanian. Jakarta : Penebar Swadaya

[10] ACIAR. 2012. Membuat Rantai Nilai Lebih BeIDRihak Pada Kaum Miskin : Buku . Pegangan Bagi Praktisi Rantai Nilai , E-book. Tabro . Indonesia.

[11] Koesmara , Hendra. 2015. Faktor-faktor yang Mempengaruhi Margin Pemasaran Sapi Potong dan Daging Sapi di Kabupaten Aceh Besar. Buletin Peternakan.https://journal.ugm.ac.id/buletinpeternakan/article view File/6160/4857. Diakses 5 September 2019. 